\title{
Rooting of Olive Varieties in Correlation with IBA Treatment in Different Concentrations
}

\author{
Rakip Iliazi*, Adem Salillari and Hairi Ismaili \\ Agricultural University of Tirana, Albania \\ *Corresponding author
}

\author{
A B S T R A C T
}

\begin{tabular}{|l|}
\hline K e y w o r d s \\
$\begin{array}{l}\text { Olive varieties, } \\
\text { Correlation, IBA } \\
\text { treatment. }\end{array}$ \\
\hline Article Info \\
\hline $\begin{array}{l}\text { Accepted: } \\
\text { 29 September } 2017 \\
\text { Available Online: } \\
\text { 10 October } 2017\end{array}$ \\
\hline
\end{tabular}

This study deals the biological processes of root formation of the five olive varieties in correlation with IBA treatment in different concentrations. The method consisted of five olive cultivars and five concentrations of indol butyric acid (IBA), with the greenish method, and nebulization. Experimental varieties have been: Kalinjot, Koker madh Berati, Ullastra, Nisjoti, Frantoio. While dose of IBA ppm concentration have been: Control (no treatment), IBA 2000 ppm, IBA 4000 ppm, IBA 6000 ppm, IBA 8000 ppm. The results have verified that cultivars react differently to different doses of IBA in terms of rooting of the pieces. Generally, dose of $4000 \mathrm{ppm}$ provides a higher percentage of rooting, except Ullastra variety where rooting best ensure dose of $6000 \mathrm{ppm}$. By cultivars studied KMB appeared fewer rooting during treatment with IBA. As a conclusion, the ways IBA has been given in this multiplication approach has been defined and it has resulted the advantages of this multiplication manner are various

\section{Introduction}

Olea family diversity reflects the quantity, the variety and the diversity of varieties, forms and biotypes. Diversity in the family of species, between species, and between ecosystems, is considerably transformed under the influence of human activities.

Olive groves of Albania lies on the eastern shore of the Mediterranean and is considered as an important point for biological diversity because is part of the fifth center's with Mediterranean climate origin and formative of cultivated plants. Research on resource management, study and their improvement, are priority activities and have scientific and economic character of national importance, (Ismaili, et al., 2011; Hartmann, 1952)
In this context the problem remains the accelerated production of planting. Achieved not only through the addition of materials with a high biological value of production, but also for the production of clean planting materials by phytosanitary problem of saplings made in the traditional way by grafting of wild saplings (Fabri et al., 2004), which required relatively long time (about 3 years), in preparation for planting olive saplings new. But use of phytohormones in the production of olive seedlings same largely as a method which provides an accelerated production and genetically pure also and phitosanitary (Bartolini et al., 1998; Bouillenne et al., 1933). In this regard, phytoregulator IBA (indol-butyric acid), has 
an extensive use, which provides an anchoring on numerous pieces, like dormant plant as well as those in vegetation plant.

But it should be noted that different cultivars, react in different ways for doses, timing and conditions of treatment in terms of rooting and production of seedlings ready for plant new (Kurd et al., 2010). It allows plants to enter into the resulting production (which are able to fructify during the first year of their planting), when these deriving from the traditional method go through a more or less long juvenile period (Hartmann et al., 2002).

According to some researchers, Indigenous cultivars are not studied in depth associated with doses of use of indole butyric acid. The application on vegetative cultivar pieces of "Kryps Berati" cultivar, does not gave satisfactory results in rooting. Thus the study of the effect of doses of IBA concentration on indigenous olive cultivars is of interest especially for farmers dealing with the creation of new olive groves. But the use of hormones for rooting has some problems to be solved, such as phytohormones doses concentration, retention time in the phytohormones and combination with other materials etc, (Ciampi et al., 1958; Fernandes et al., 2003).

In these circumstances we have experimented with the ability of rooting for some autochthonous cultivars, callogenesis, time, dosage and time of treatment, to increase the quality of the seedlings and to successfully use the plant.

\section{Materials and Methods}

Green cuttings of the five olive cultivars are tested for their rooting capacity with the nebulization method, in correlation with five concentrations of indol-3 butyrik acid (AIB) and (Control).
The object of the study is the formation of callus and the roots of the five pieces vegetative variation of olive, in five concentrations of IBA, of which four are indigenous variation and one of these is cultivar Frantoio.

Experimental varieties have been: Kalinjot, Kokermadh Berati, Ullastra, Nisjoti, Frantoio. While dose of IBA ppm concentration have been: Control (no treatment), IBA 2000 ppm, IBA 4000 ppm, IBA 6000 ppm, IBA 8000 ppm.

Green cuttings have been taken from 10-year old trees. Rooting period has been every month on the fifth day. The green cuttings are $8-10 \mathrm{~cm}$ long, having two pairs of leaves at the apical, with all the leaves at the base being cut off. Each treatment has 50 cuttings. The 5 sec. treatment with hydro alcoholic solution of indol butyric acid (ecyberon). A Control treatment has been considered and applied as comparative.

The cuttings have been planted at nebulization bank. within the biological green house, with perlite subtract. Temperature has been kept at $20^{\circ} \mathrm{C}$ and at $24^{\circ} \mathrm{C}\left( \pm 1^{\circ} \mathrm{C}\right)$ in the subtracts. Nebulization has been achieved for $5 \mathrm{sec}$.

\section{Indicators that were analyzed}

Initiation of callus from the treatment until the start of callus. Start of rooting (day) from the treatment until the start of callus. Completion of rooting (day) from the treatment until the end of rooting. The average number of first roots formed for each variant. The number of pieces of callus and rooted.

\section{Statistical analysis}

It has been carried out by means of software modeled for 50 green cuttings for each 
treatment. The Variance Analysis for TukeyKramer test and All Pearch, $(\mathrm{P}=0.05)$ has recognized and certified the differences of each treatment (Jmp.Sas/Stat.2008)

\section{Results and Discussion}

The application on vegetative cultivar pieces of "Kryps Berati" cultivar, does not gave satisfactory results in rooting. In this article we focus on the number of pieces that were callus and rooted. The study has confirmed that all biological, anatomical and physiological characteristics have been correlated and have contributed to the rooting performance. The first indicator was the average percentage of cuttings in correlation with five different concentrations of IBA. The data of percentage presented in table-1, shows that the percentage of cuttings rooted varies as by doses of the concentration to other or from one genotype to another. With the largest number of pieces rooted presents Kalinjot cultivar with $86.7 \%$ in $4000 \mathrm{ppm}$ dose, while the percentage of lower dose is Nisjot cultivar of $4000 \mathrm{ppm}$ and $\mathrm{KMB}$ cultivar with $36.7 \%$ in 4000 ppm dose.

Seeding the whole data of this table shows that the dose which provides a greater percentage of rooted pieces is $4000 \mathrm{ppm}$ dose. This is confirmed by studies of the authors to give the approximate dose that we used in this study.

The IBA dose and period of time. Some cultivars have registered extreme values of the rooting percentages in different concentrations of the hormone. It was proved that not all three treatments affected in the same way the rooting result of the olive cuttings at any tested term. Both concentrations of the Indole -3- Butyric Acid (IBA), have influenced differently. Rooting percentage is considerably obvious, not only for the dose 2000ppm, but also for $8000 \mathrm{ppm}$, whereas for other varieties there has been either one dose or the other with regard to only one typical rooting term. The Kaninjot cv has had an extremely high rooting percentage in both concentrations: with IBA 5000ppm (86.7\%). A high rooting percentage has also resulted for Ullastra and Frantoio cv, table-1, whereas the cultivars; Kryps Berati (KB) and Nisjot (Nis), have displayed low rooting percentage. The above mentioned cultivars although displaying sufficient callus size, after 20-25 days, their callus increases in volume, and becomes like a spongy mass, that it can't reach rooting, (Caballero, 1993).

In Fig.1, the percentage of rooting of each cultivar is seen, verifying the phenomenon of the variability of olive cultivars for the ability to rooted.

The Fig.2, figuratively is the variance analysis, it is seen that cultivators have different abilities to rooted. Treatment Control for each cultivar has had a lower rooting percentage compared to hormone treatments.

Hormones in each concentration have added rotting ability to each cultivar. Average rotting percentage was $45.6 \%$ for all cultivars, but cultivars and concentrations of IBA, increased the variability of these data. Amplitude of each index has been very high for each cultivar. The data are verified by the variance level $\mathrm{q}=3.873$ and alpha 0.05 . In this way it has resulted versus Prob> F <.0001 $*$, the search results are highly substantiated because F Ratio resulted to be much greater (3578.58).

According to the analysis of results, results with a strong positive correlation between the beginning of the callus and the start of rooting. This indicates that these two processes go in parallel and have strong biological link. 
Table.1 The average data of rooting of five olive genotypes treated with five concentrations IBA

\begin{tabular}{|l|c|c|c|c|c|}
\hline Treatment & Kalinjot & Koker madh Berati (KMB) & Ullaster & Nisjot & Frantoio \\
\hline Control & $26.3 \pm 0.84 \mathrm{IJ}$ & $5.3 \pm 0.19 \mathrm{M}$ & $24.0 \pm 0.93 \mathrm{~J}$ & $5.3 \pm 0.21 \mathrm{M}$ & $24.0 \pm 0.33 \mathrm{~J}$ \\
\hline IBA 2000 ppm & $68.7 \pm 0.16 \mathrm{D}$ & $20.7 \pm 0.40 \mathrm{~K}$ & $58.7 \pm 0.66 \mathrm{~F}$ & $16.7 \pm 0.68 \mathrm{~L}$ & $37.5 \pm 0.22 \mathrm{G}$ \\
\hline IBA 4000 ppm & $86.7 \pm 0.42 \mathrm{~A}$ & $36.7 \pm 0.48 \mathrm{G}$ & $78.7 \pm 0.78 \mathrm{C}$ & $32.7 \pm 0.9 \mathrm{H}$ & $62.7 \pm 091 \mathrm{E}$ \\
\hline IBA 6000 ppm & $83.3 \pm 0.62 \mathrm{~B}$ & $32.0 \pm 071 \mathrm{H}$ & $83.3 \pm 0.34 \mathrm{~B}$ & $31.3 \pm 0.42 \mathrm{H}$ & $67.3 \pm 1.21 \mathrm{D}$ \\
\hline IBA $8000 \mathrm{ppm}$ & $78.7 \pm 0.78 \mathrm{C}$ & $27.2 \pm 0.14 \mathrm{I}$ & $67.3 \pm 0.55 \mathrm{D}$ & $31.3 \pm 0.55 \mathrm{H}$ & $60.2 \pm 1.23 \mathrm{EF}$ \\
\hline
\end{tabular}

Levels not connected by same letter are significantly different.

Fig.1 The percentage of cuttings rooted (\%) of five olive genotypes

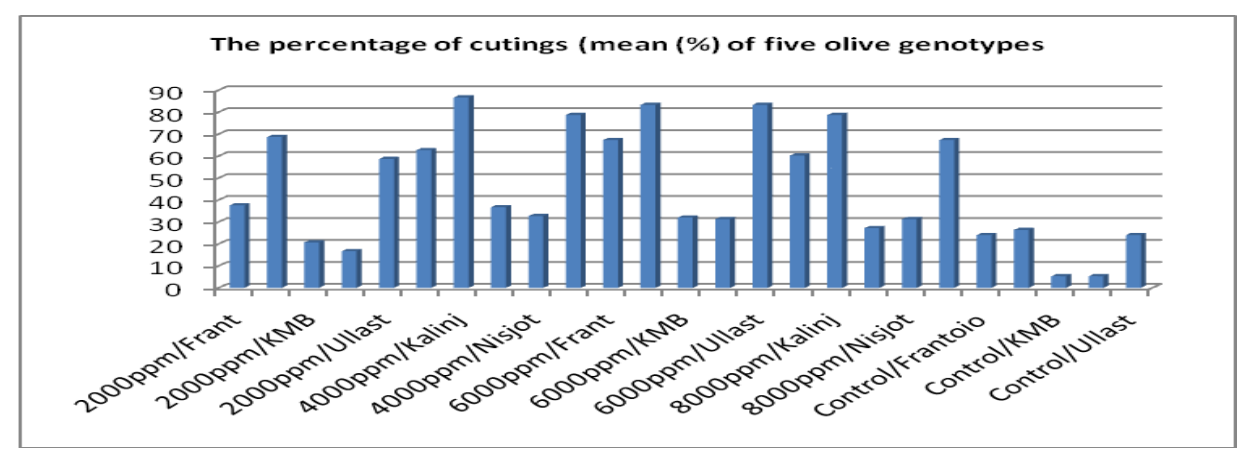

Fig.2 Oneway Analysis of Percentage (\%) of variety by Treatment

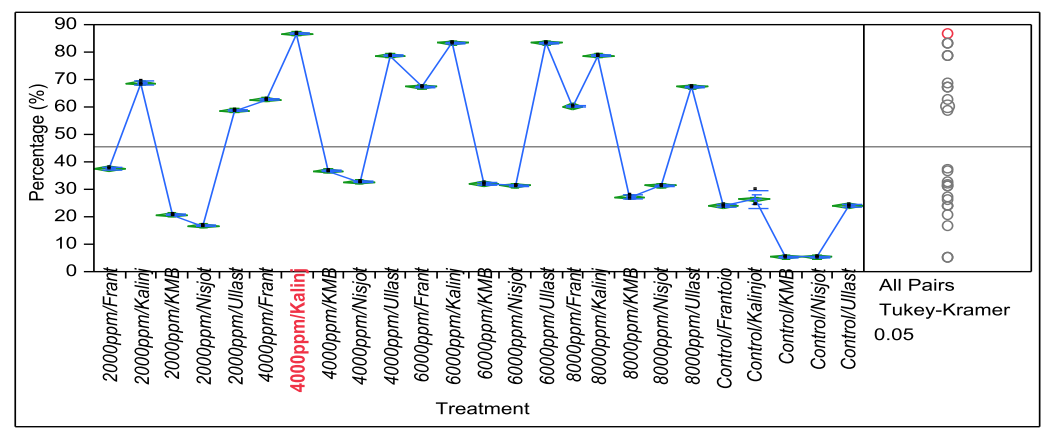

Fig.3 Oneway Analysis of Callog. Without Rhiz. (\%) By Treatment of five olive genotypes treated with five IBAs concentrations

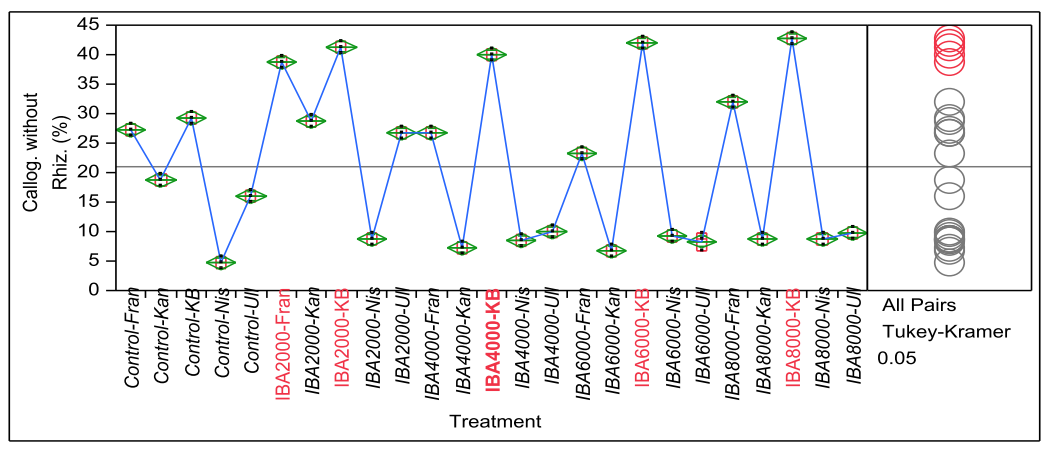


Strong positive links are also observed between the number of the first roots, the length of the pieces and the number of rooted pieces. The same results were presented by Ciampi, Bartolini and Ismaili.The rooting process correlates negatively with the number of first roots, the length of the pieces and the number of rooted pieces. In this case, the correlation coefficients do not change in the extent of occurrence among the analyzed cultivars.

The correlation coefficients have a large amplitude between the rooted start and the number of first roots, from $\mathrm{r}^{2}=-0.98$ for the Kalinjot cultivar to $r^{2}=-0.55$ for the Frantoio cultivar. Referring to the correlation coefficient shows that the amount of such connections there are similarities between them. The doses of IBA 4000 - 6000 ppm, were efficient in correlation with the cultivars when they were used, thus giving a maximal increase of the rooting percentage and leaves resistance up to the end of the rooting process.

Higher percentage of rooting for Kalinjot, KMB and Nisjot cultivars presents dose concentration of 4000 ppm IBA. As for Frantoio and Ullastra cultivar is $4000 \mathrm{ppm}$ and 6000 doses give approximetly results. By cultivar that rooted in small percentage is $\mathrm{KMB}$.

The advantages of this multiplication manner are various; a conceivable multiplication within a short period of time as well as high multiplication coefficient of thousands of exemplars from a parent tree, which are considerably homogenous among them.

\section{References}

Bartolini, G., A. Fabbri and M. Tattini. 1988a. Effect of phenolic acids on rhizogenesis in a grape rootstock (,,140 Ruggerie) cuttings. Acta Horticulturae, 227: 242247.

Bouillenne, R. \& Went, F.W. 1933. Recherches experimentales sur la neoformation des racines dans les plantules et les boutures des plantes superieures. Annuel Jardin Botanique Buitenzorg, 43: 25-202.

Caballero JM., 1983: La multiplication de $1^{\text {ee }}$ olivier par bouturage semi-ligneux sous nebulisation. 1983. Bul.FAO. P 13-36

Ciampi, C. \& Gellini, R. 1958. Studio anatomico sui rapporti tra struttura e capacita di radicazione in talee di olivo. Nuovo Giorn. Bot. Ital., 65: 417-424.

Fabbri, A., G. Bartolini, M. Lambardi and S. Kailis. 2004. Olive Propagation Manual. Landlinks Press, Collingwood, 141 pp.

Fabbri., A. 1980. Influenza di alcuni caratteri anatomici sulla radicazione di talee di olivo cv „Frangivento ${ }^{\text {ce }}$ Riv. Ortoflorofrutt. Ital., 64, (4): 325-335.

Fernandes Serrano, J.M., M.C. Serrano and E. Amaral. 2002. Effect of different hormone treatments on rooting of Olea europaea cv. Galega vulgar cuttings. Acta Horticulturae, 586:875-877.

Hartmann, H.T. 1952. Further studies on the propagation of the olive by cuttings. Proc. Amer. Soc. Hort. Sci., 59: 155-160.

Hartmann, H.T., D.E. Kester, F.T. Davies and R.L. Geneve. 2002. Plant Propagation, Principles and Practices. 7 th Ed., Prentice Hall, New Jersey, 880 pp.

Ismaili H., Ianni G., Dervishi A., 2011: Study of Main Factors Influencing Olive Propagation. J. Int. Environ. Appl. \& Sci. 2011; 6(4):623-639. ICID: 971170.

Jmp.Sas/Stat. 2008t: Statistical Analysis with Software. SAS users guide, 2008. version 6. Institute Inc., Cary, N.C.

\section{How to cite this article:}

Rakip Iliazi, Adem Salillari and Hairi Ismaili. 2017. Rooting of Olive Varieties in Correlation with IBA Treatment in Different Concentrations. Int.J.Curr.Microbiol.App.Sci. 6(10): 4825-4829. doi: https://doi.org/10.20546/ijcmas.2017.610.450 